\section{Immunologic and genotoxic profile of Northern Gannet (Morus bassanus) from Bonaventure Island}

\author{
C. Brousseau-Fournier, ${ }^{1-3}$ E. Lacaze, ${ }^{2}$ \\ L. Champoux, ${ }^{4}$ M. Fournier, ${ }^{1-3}$ \\ P. Brousseau ${ }^{1-3}$
}

'Parc de la rivière Mitis, Ste-Flavie, QUE; ${ }^{2}$ Institut National de la Recherche Scientifique-Institut Armand-Frappier, Laval, QUE; ${ }^{3}$ Université du Québec à Rimouski, Rimouski, QUE, Canada; ${ }^{4}$ Environnement Canada, QUE Canada

\section{Introduction}

The Northern Gannet is the biggest marine bird to nest in the St-Lawrence. The Bonaventure Island colony is one of the most important gannet colony in the world with about $70 \%$ of total North America population. ${ }^{1}$ However, since a few years that number is lowering. Indeed, the reproductive success of gannet went from $76 \%$ in 1979 to a critical $8 \%$ in $2012 .^{2}$ Thus, the number of nesting couple got lowered by 12,000 . Since the gannets are migratory birds at the top of the food web, they are susceptible to be exposed to a wide variety of stressors and to bioaccumulate pollutants. Thus, gannets monitoring studies are essential in providing insight into possible environmental damage. We therefore decided to investigate two major biological responses: the immune response and DNA damage.

On one hand, the study of the immune system of those birds could allow to pinpoint an explanation to this drastic decrease in their population. On the other hand, DNA damage related to environmental genotoxicants is a crucial point as they can lead to mutations and developmental impairment or cancer occurrence. DNA damage can negatively impact individual organism fitness, reproductive success, and subsequently, population dynamics. ${ }^{3}$

However, since biomarkers of immunotoxicity and genotoxicity where never applied to the gannet we had first to demonstrate that these research tools could be used adequately to the Northern gannet.

The immune system of bird is composed of 2 types of defensive pathways: the non-specific immunity and the specific immunity. The nonspecific defense comprises various tools ranging from physical and biochemical barriers, to soluble and cellular components. The cells associated with the non-specific pathway are mainly heterophils (equivalent of mammal's neutrophils). The specific immunity is based on the antigens recognition and is provided by 2 types of leukocytes which are B and T cells.

In our immunologic analysis we focused on the heterophils and their phagocytic capabilities whereas the genotoxicity was evaluated using the Comet assay on erythrocytes.

\section{Materials and Methods}

\section{Animals and blood collection}

On the Bonaventure Island (48.4972799N, 64.1618626W), gannets marked with a Fish and Wildlife Service steel ring and monitored since 2008. Some were caught using a pole with a noose. While 2 people were holding the bird the veterinarian was taking blood samples immediately following capture from the brachial vein and collected in $5.0 \mathrm{~mL}$ heparinized tubes. The blood samples were brought back in a field laboratory on the day of collection.

\section{Determination of cell viability}

The viability of white blood cells, was determined by flow cytometry using propidium iodide (PI). Briefly, $1 \mu \mathrm{L}$ of a $1 \mathrm{mg}$ mL-1 stock solution of PI (Sigma Chemical Co., St. Louis, MO, USA) was added to each cell suspension and flow cytometric acquisition of these suspensions was performed. PI is an exclusion dye that binds to the nucleic acid of dead cells which become strongly fluorescent. Fluorescence emission was collected at 670 $\mathrm{nm}$. The results are expressed in percent of viable cells.

\section{Monitoring of phagocytosis}

A volume of $100 \mu \mathrm{L}$ of peripheral blood was mixed with yellow-green latex FluoSpheres (Molecular Probes Inc., Eugene, OR, USA) at a ratio of 1:100 (leukocytes:beads) in Eppendorf tubes. After an incubation of $1 \mathrm{~h}$ at $40^{\circ} \mathrm{C}$, the cells were washed once with phosphate buffered saline (PBS), recovered by centrifugation at $150 \mathrm{x} \mathrm{g}$ at room temperature and resuspended in $200 \mu \mathrm{L}$ of PBS and flow cytometric acquisition was performed. Fluorescence emission was collected at 533/30 $\mathrm{nm}$. The results are expressed in percent of phagocytic cells containing 1 bead and more and 3 beads and more.

\section{Flow cytometry acquisition}

A BD Accuri ${ }^{\mathrm{TM}}$ C6 (Becton Dickinson, San Jose, CA, USA) providing an excitation at 488 $\mathrm{nm}$ was used. Heterophils were defined based on their forward and right angle scatter properties. A total of 10,000 events were acquired for each sample. The data were then analyzed, once displayed as two-parameter complexity and cell size, in the process of gating and as fluorescence (FL1 and FL3) frequency distribution histogram. Data collection and analysis
Correspondence: Michel Fournier, Institut National de la Recherche Scientifique-InstitutArmand-Frappier (INRS-IAF), 531 boul. des Prairies, Laval, Québec, Canada H7V 1 B7.

E-mail: michel.fournier@iaf.inrs.ca

Key words: genotoxic profile, Morus bassanus, Bonaventure Island.

Conference presentation: ECOBIM meeting, 2014 May, Brest, France.

This work is licensed under a Creative Commons Attribution NonCommercial 3.0 License (CC BYNC 3.0).

(C) Copyright C. Brousseau-Fournier et al., 2014

Licensee PAGEPress, Italy

Journal of Xenobiotics 2014; 4:4891

doi:10.4081/xeno.2014.4891

were performed with the BD Accuri ${ }^{\mathrm{TM}} \mathrm{C} 6$ software.

\section{Comet assay}

Before proceeding the alkaline Comet assay, blood samples of each bird were checked for cell density and viability with Trypan blue dye exclusion assay. Cell concentrations were adjusted to $5 \times 10^{5}$ cells $/ \mathrm{mL}$ with PBS and samples were divided in two batches: one batch was exposed to $1 \mathrm{mM}$ of methyl methane sulfonate (MMS) for $15 \mathrm{~min}$ at $4^{\circ} \mathrm{C}$ in the dark, whereas the other one was kept in the same conditions without MMS treatment. The Comet assay was then basically performed on both batches according to the procedure described by Singh et al. ${ }^{4} \mathrm{~A}$ volume of $20 \mu \mathrm{L}$ of blood was mixed with $20 \mu \mathrm{L}$ of $1 \%$ low melting point agarose prepared in PBS. This mixture was spread on a frosted microscope slide precoated with normal agarose (1\%), and was covered with a $22 \times 22 \mathrm{~mm}$ coverslip (two gels per slide). Coverslips were withdrawn after agarose polymerization $\left(4^{\circ} \mathrm{C}, 10 \mathrm{~min}\right)$, and slides were incubated for 1 hour in a lysing solution (2.5 M NaCl, $0.1 \mathrm{M} \mathrm{Na2EDTA,} 10 \mathrm{mM}$ Tris, $10 \%$ DMSO, $1 \%$ Triton X100; pH 10) at $4^{\circ} \mathrm{C}$ in the dark. The slides were then placed $20 \mathrm{~min}$ in an electrophoresis buffer $(0.3 \mathrm{M} \mathrm{NaOH}$ and $1 \mathrm{mM}$ Na2EDTA, pH>13) to allow the unwinding of DNA. Electrophoresis was carried out at $0.8 \mathrm{~V} / \mathrm{cm}$ and $300 \mathrm{~mA}$ for $24 \mathrm{~min}$. Slides were then washed three times for 5 min with a neutralization buffer ( $0.4 \mathrm{M}$ Tris- $\mathrm{HCl}, \mathrm{pH} 7.5)$ and dried in absolute ethanol. After staining with Sybr Green solution, each slide was viewed by fluorescence microscopy (*400). Results were gained by a visual scoring system, for which a total of 100 randomly selected cells on each gel were classified as belonging to one of five categories of comets according to the tail and head intensity. ${ }^{5}$ 


\section{Statistical analysis}

Results were expressed as mean \pm SD. For immune response, each parameter was assessed using one-way analysis of variance (ANOVA). SigmaPlot (version 3.5) was used. For genotoxicity, differences between DNA damage in male and female and between blood samples were tested using Mann Whitney U test.

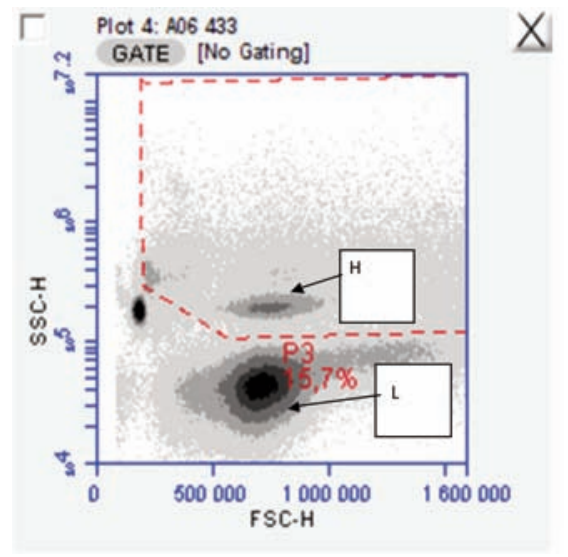

Figure 1. Example of gannet blood cells populations using a $\mathrm{BD}$ Accuri ${ }^{\mathrm{TM}} \mathrm{C} 6$ using a density plot of complexity versus size of the cells.

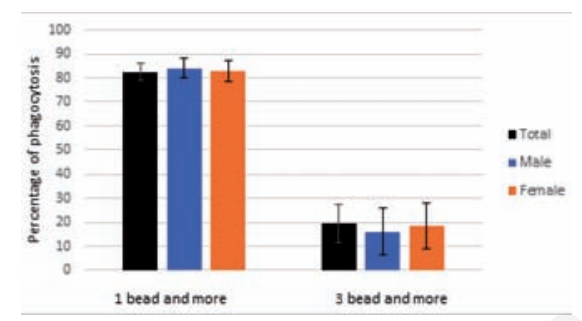

Figure 2. Mean of $\%$ phagocytic cells in heterophils.

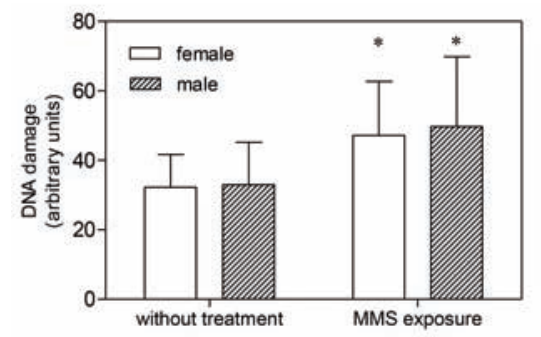

Figure 3. DNA damage measured in Morus bassanus erythrocytes before and after methyl methane sulfonate (MMS) exposure (mean $\pm S D$; female $\mathrm{N}=6$; male $\mathrm{N}=10$ ). ${ }^{*}$ Denotes statistically significant difference $(\mathrm{P}<0.05)$ compared to batches without treatment.

Table 1. Mean of $\%$ of lymphocytes, heterophils and $\mathrm{H} / \mathrm{L}$ ratio. The results are expressed as mean \pm standard deviation.

\begin{tabular}{lcccc} 
& No. & $\% \mathrm{~L}$ & $\% \mathrm{H}$ & Ratio H/L \\
Entire cohort & 36 & $66.3 \pm 4.5$ & $11.3 \pm 2.9$ & $0.18 \pm 0.05$ \\
Males & 13 & $62.9 \pm 10.9$ & $13.2 \pm 2.8$ & $0.22 \pm 0.09$ \\
\hline Females & 7 & $69.9 \pm 4.0$ & $11.5 \pm 1.2$ & $0.17 \pm 0.03$ \\
\hline
\end{tabular}

\section{Results and Discussion}

\section{Identification of peripheral blood cell populations}

Using a density plot of the complexity (SSC) versus the size of the cells (FSC), we could discriminate 2 cell populations, $\mathrm{L}$ and $\mathrm{H}$ (Figure 1).

The population L with small and less complex cells are the lymphocytes and the population $\mathrm{H}$ with more complex cells is the heterophils. Ecotoxicological field studies on birds although limited take advantage of using the $\mathrm{H} / \mathrm{L}$ ratio. Among applications of this ratio one of them is being an indicator of stress-status in wild birds. ${ }^{6}$ Therefore $\mathrm{H} / \mathrm{L}$ ratio were calculated for each animal based on the \% of heterophils and lymphocytes obtained in the density plot. Results for the entire cohort and from males and females separately are presented in Table 1 . A mean of $66.3 \%$ and $11.3 \%$ of lymphocytes and heterophils has been respectively measured for $\mathrm{H} / \mathrm{L}$ ratio a mean of 0.18 has been obtained. For all parameters measured, no significant differences between males and females were revealed. By comparing this ratio with those obtained from literature, gannet ratio appeared to be the smallest documented so far. Indeed, the ratio for the black caped chickadee is 0.29 , the ring-billed gull is 1.23 the great tit is 1.2 and finally the bald eagle is $6.20{ }^{6-8}$ While hematological parameters become more and more popular in ecotoxicology study of wild vertebrates, more experiments are needed to understand why gannet has this low $\mathrm{H} / \mathrm{T}$ ratio and if this ratio remains constant during breeding season.

\section{Phagocytosis}

Results for phagocytic activity of heterophils are presented in Figure 2 for the whole cohort as well as for males and females separately.

A mean percentage of phagocytic activity (1 bead and more) and efficiency ( 3 beads and more) of $82.6 \pm 4.4$ and $19.5 \pm 9.6$ respectively has been obtained for the entire cohort. When results were analyzed for males and females separately no significant differences between them were pointed out.

\section{Genotoxicity}

While a high level of DNA damage was measured in cells without genotoxicant treatment, a significative increase is gained after MMS exposure, validating the protocol applied. Such high DNA damage in bird erythrocytes has been previously described (Figure 3). No differences between male and female have been denoted, however, the effect of age should also be taken into account, to avoid misunderstanding of results in the case of biomonitoring studies.

\section{Conclusions}

In conclusion, these methods can be used adequately to follow the health status of the Northern Gannet population from Bonaventure Island. However, complementary studies should be conducted to take into account the influence of several parameters such as age, period of breeding season when captured, and wintering migratory area.

\section{References}

1. Chardine JW, Rail J-F, Wilhelm S. Population dynamics of Northern Gannets in North America, 1984-2009 J. Field Ornithol. 2013;84:187-92.

2. Rail JF. Île Bonaventure: la survie des fous de Bassan menacée. LeSoleil, 1 0ct 2013. Available from: http://www.lapresse.ca/lesoleil/actualites/environnement/201309/30/014694993-ile-bonaventure-la-survie-desfous-de-bassan-menacee.php

3. Anderson SL, Wild GC. Linking genotoxic responses and reproductive success in ecotoxicology. Environ Health Perspect 1994;102:9-12.

4. Singh NP, McCoy MT, Tice RR, Schneider EL. A simple technique for quantitation of low levels of DNA damage in individual cells. Exp Cell Res 1988;175:184-91.

5. Collins AR, Dobson VL, Dušinská M, Kennedy G, Stětina R. The comet assay: What can it really tell us? Mutat Res Fund 
Mol M 1997;375:183-93.

6. Muller C, Jenni-Eiermann S, Jenni L. Heterophils/Lymphocytes-ratio and circulating corticosterone do not indicate the same stress imposed on Eurasian kestrel nestlings. Funct Ecol 2011;25:566-76.
7. Davis AK, Maney DL, Maerz JC. The use of leukocyte profiles to measure stress in vertebrates: a review for ecologists. Funct Ecol 2008;22:760-72.

8. Krams I, Vrublevska J, Cirule D, Kivleniece I, Krama T, Rantala MJ, et al.
Heterophil/lymphocyte ratios predict the magnitude of humoral immune response to a novel antigen in great tits (Parus major). Comparat Biochem Physiol Part A 2012;161:422-8. 